\title{
Evaluating Breed Complementarity and Sexed Semen with Maternal Use of Afrikaner Germplasm
}

\author{
Razie Khorshidi' ${ }^{1}$, Michael D. MacNeil2,3,4, John J. Crowley ${ }^{1,5}$, Michiel M. Scholtz ${ }^{3,4}$, \\ Annette Theunissen ${ }^{6}$, Graham S. Plastow ${ }^{*}$ \\ ${ }^{1}$ Livestock Genetic, Department of Agricultural, Food, and Nutritional Science, University of Alberta, Edmonton, Canada \\ ${ }^{2}$ Delta G, Miles City, USA \\ ${ }^{3}$ ARC-Animal Production Institute, Irene, South Africa \\ ${ }^{4}$ Department of Animal, Wildlife and Grassland Sciences, University of the Free State, Bloemfontein, South Africa \\ ${ }^{5}$ Canadian Beef Breeds Council, Calgary, Canada \\ ${ }^{6}$ Department of Agricultural, Land Reform and Rural Development, Jan Kempdorp, South Africa \\ Email: *plastow@ualberta.ca
}

How to cite this paper: Khorshidi, R., MacNeil, M.D., Crowley, J.J., Scholtz, M.M., Theunissen, A. and Plastow, G.S. (2017) Evaluating Breed Complementarity and Sexed Semen with Maternal Use of Afrikaner Germplasm. Agricultural Sciences, 8, 507-517. https://doi.org/10.4236/as.2017.87038

Received: April 27, 2017

Accepted: July 1, 2017

Published: July 4, 2017

Copyright (C) 2017 by authors and Scientific Research Publishing Inc. This work is licensed under the Creative Commons Attribution International License (CC BY 4.0).

http://creativecommons.org/licenses/by/4.0/

\begin{abstract}
Livestock production impacts food security of developing countries, especially where efficiency of production is compromised by environmental stressors. In South Africa, breeding with indigenous Afrikaner cattle that are genetically well adapted to subtropical environments is considered an essential strategy for sustainable beef production. Today, there is a potential for farmers to participate in commercial systems that join adapted Afrikaner germplasm, used in a specialized maternal role, with exotic terminal sires to optimize production. The objective of this study was to assess productivity of five simulated production systems: 1) straightbred Afrikaner mated naturally, 2) a straightbred Afrikaner cow herd with two sections; one section to produce replacement females and the other to cross with Charolais terminal sires, both using natural mating, 3) similar to 2, but applying sexed semen to produce replacement females, 4) similar to 2, but using a multi-breed composite dam line with a breed combination of 50\% Afrikaner, 25\% Hereford and 25\% Simmental, and 5) similar to 4, but again applying sexed semen to produce replacement females. Parameter estimates needed to compare these systems were extracted from the scientific literature. Relative to straightbred Afrikaner dams, the simulated composite dams were more fit producing $7.8 \%$ more calves and their progeny performance was improved by reducing feed intake $(-24.4 \%)$ and increasing meat production $(+11.7 \%)$. The potential benefit of allocating more cows to the terminal sire was insufficient to offset the reduction in pregnancy rate that results with the use of sexed semen. Thus, system 4 had
\end{abstract}


the greatest productivity $(+23.1 \%)$ while requiring $22.8 \%$ less feed for finishing the progeny to be harvested relative to the purebred Afrikaner system. The combination of increased productivity and reduced feed requirement made use of a Charolais terminal sire in conjunction with multi-breed composite females bred by natural service the most efficient system among those studied.

\section{Keywords}

Beef Production, Afrikaner, Composite Dams, Sexed Semen, Terminal Crossbreeding

\section{Introduction}

Livestock production impacts food security of millions of people all over the world, and especially in developing countries [1] [2]. Moreover, animal products are the most important income generator for smallholders in such countries. There is potential for emerging farmers to enhance productivity and alleviate poverty by entering a viable market for their animals [3] [4] [5].

In subtropical environments stressors including heat, humidity, disease, parasites and poor nutrition seriously compromise livestock production efficiency and under these conditions use of adapted straightbred germplasm is potentially beneficial [6]. In South Africa, the indigenous Afrikaner, Nguni, and Drakensberger beef breeds exhibit specific adaptive features that allow them to thrive in such environments where exotic breeds are less fit [7].

Achieving optimal levels of reproduction, growth, milk production, food consumption, and carcass merit challenges beef producers as they may be environmentally constrained [6] and antagonistically correlated [8] [9] [10] while also influencing both productivity and profitability. Thus, implementing technologies that simultaneously reduce costs and carbon footprint while improving beef production efficiency is considered increasingly important [11] [12]. Crossbreeding can accomplish these goals by providing benefits from heterosis and breed complementarity [13] [14].

Indigenous Afrikaner cattle may be well suited for use as a specialized dam line because they benefit from limited calving difficulties and are well adapted to subtropical environments, while joining them with sires from an exotic terminal sire can improve feedlot performance and meat yield of F1 progenies [5] [15]. Use of Charolais as a terminal sire simplifies management of the crossbreeding system due to its mutation in the SILV gene [16] that facilitates sorting maternal progenies from their Charolais sired counterparts using only coat color. Creation of a multi-breed composite dam line allows exploitation of maternal heterosis with potentially little effect on environmental adaptation [17] [18]. Use of a multi-breed composite dam line not only takes advantage of heterosis, but also by fixing different breed proportions further simplifies management compared to rotational crossbreeding [19]. 
Successful implementation of crossbreeding requires that at least part of the herd be allocated to production of replacement females. Therefore, use of sexed semen could contribute to increased productivity by allocating fewer cows to generation of replacements while utilizing the remainder for production of terminal cross progeny [20]. This might mitigate the inefficiency that originates from less beneficial male offspring produced by the dam line [21]. However, use of sexed semen depends on the ability to successfully implement artificial insemination and opportunities for emerging farmers to use this technology are only now being explored in South Africa [22].

Systems analysis provides a means for simultaneous consideration of many more factors than could feasibly be included in one experiment and may be a realistic method of developing or testing recommendations to improve production efficiency [23]. The aim of this paper is to investigate opportunities for use of crossbreeding and sexed semen technologies to improve the production efficiency relative to a system that is based on straightbred Afrikaner cattle. Herein experimental results taken from the scientific literature are summarized using simulation.

\section{Materials and Methods}

The data used for the simulations described herein came from previously published literature. No animals were used directly in the performance of this research. Thus, approval from the Institutional Animal Care and Use Committees of the authors was not sought. The original research upon which these simulations were based came from experimentation carried out at the Vaalharts Research Station, near Jan Kempdorp, South Africa. The Vaalharts Research Station is located at $27^{\circ} 51^{\prime}$ south and $24^{\circ} 50^{\prime}$ east at an altitude of 1175 meters. Carcass data were collected at the Animal and Dairy Research Institute, Irene, South Africa. Thus, parameters for the simulation experiments described hereafter were drawn from previously published literature [18] [24] [25] [26].

Alternative self-sustaining systems were simulated with a deterministic model to evaluate their potential for improving productivity relative to a system based on straightbred Afrikaner cattle. Two of the alternative systems employed Afrikaner females as a specialized dam line and two considered a multi-breed composite female comprised of 50\% Afrikaner, $25 \%$ Hereford and $25 \%$ Simmental as the specialized dam line. In two of the systems sexed semen was used to increase the proportion of females that could be allocated to the terminal sire. The systems were as follows:

1) A straightbred production system using Afrikaner cattle and natural service;

2) A specific-cross production system using Afrikaner females, Charolais terminal sires and natural service;

3) Similar to system 2, but with sexed semen used to produce the straightbred Afrikaner replacement females;

4) Similar to system 2, but with the Afrikaner females being replaced with the 
multi-breed composite females; and

5) Similar to system 4, but with sexed semen used in generation of the replacement females.

Structural equations used in the simulation were as follows:

$$
R R=1-P R
$$

where $R R=$ replacement rate and $P R=$ pregnancy rate, assuming that nonpregnant females were culled at the time of pregnancy testing (approximately coincident with weaning).

$$
W R=P R \times S R
$$

where $W R=$ weaning rate and $S R=$ calf survival rate.

$$
P=W R \times 440 \times D P \times M Y
$$

$P=$ Production per cow, where a weight-constant endpoint of 440 kilograms was assumed, $D P=$ dressing percentage and $M Y=$ meat yield from the carcass.

$$
D O F=(440-W W) / A D G
$$

where $D O F=$ Days from weaning to harvest, $W W=$ weaning weight of the calf and $A D G=$ its postweaning average daily gain.

$$
T F I=D O F \times D F I
$$

$T F I=$ Feed consumed by the calf from weaning to harvest and $D F I=$ average daily feed intake.

Throughout a 1:1 sex ratio was assumed for calves resulting from natural mating. Thus, with natural mating the proportion of the cows that was allocated for production of replacement females $(R F)=R R / 0.5$. When use of sexed semen was simulated the expected 1:1 sex ratio was shifted to 90\% heifers [20] [21] [27] and PR was reduced by $10 \%$ [20] [28]. Thus, when use of sexed semen was simulated $R F=R R / 0.9$. There was no effect of having used sexed semen on $S R$ [27]. For female calves, $\mathrm{P}$ was reduced by $20 \%$ relative to their male counterparts [29]. Total productivity (TP) and total feed consumption (TFC) for the ith system were calculated as sum of the meat produced from male calves in the replacement section $\left(P_{R F_{i_{m}}}\right)$ or the amount of feed they consumed $\left(T F I_{M P_{i_{m}}}\right)$ as well as male and female calves in the market progeny section $(M P=1-R F)$ with equal proportions, respectively:

$$
\begin{gathered}
T P_{i}=H P_{R F_{i_{m}}} \times R F_{i} \times P_{R F_{i_{m}}}+1 / 2 \times M P_{i} \times P_{M P_{i_{m}}}+1 / 2 \times M P_{i} \times P_{M P_{i_{f}}} \\
T F C_{i}=H P_{R F_{i_{m}}} \times R F_{i} \times T F I_{R F_{i_{m}}}+1 / 2 \times M P_{i} \times T F I_{M P_{i_{m}}}+1 / 2 \times M P_{i} \times T F I_{M P_{i f}}
\end{gathered}
$$

where $H P$ represents the harvest proportion for male calves in the replacement section and corresponds to $1 / 2$ or 0.1 for natural service or sexed semen, respectively.

Breed-specific genetic effects, following [30], on the phenotypes used in the simulations for this study were taken from the previously published work of [24] [25] [26]. Specifically, phenotypes were simulated for four breed groups as follows: 


$$
\text { Straightbred Afrikaner }=G_{0}+G_{A}^{I}+G_{A}^{M}
$$

Charolais sired progeny from Afrikaner dams

$$
=G_{0}+1 / 2 G_{A}^{I}+1 / 2 G_{C}^{I}+H_{C A}^{I}+G_{A}^{M}
$$

Straightbred composite

$$
\begin{aligned}
= & G_{0}+1 / 2 G_{A}^{I}+1 / 4 G_{H}^{I}+1 / 4 G_{S}^{I}+1 / 4 H_{H A}^{I}+1 / 4 H_{S A}^{I}+1 / 8 H_{H S}^{I}+1 / 2 G_{A}^{M} \\
& +1 / 4 G_{H}^{M}+1 / 4 G_{S}^{M}+1 / 4 H_{H A}^{M}+1 / 4 H_{S A}^{M}+1 / 8 H_{H S}^{M}
\end{aligned}
$$

Charolais sired progeny from composite dams

$$
\begin{aligned}
= & G_{0}+1 / 2 G_{C}^{I}+1 / 4 G_{A}^{I}+1 / 8 G_{H}^{I}+1 / 8 G_{S}^{I}+1 / 2 H_{C A}^{I}+1 / 4 H_{C H}^{I}+1 / 4 H_{C S}^{I} \\
& +1 / 2 G_{A}^{M}+1 / 4 G_{H}^{M}+1 / 4 G_{S}^{M}+1 / 4 H_{H A}^{M}+1 / 4 H_{S A}^{M}+1 / 8 H_{H S}^{M}
\end{aligned}
$$

where $A, C, \mathrm{H}$ and $S$ designate the Afrikaner, Charolais, Hereford and Simmental breeds, $G^{I}$ and $G^{M}$ represent individual and maternal breed additive effects, and $H^{I}$ and $H^{M}$ represent individual and maternal heterosis effects. Following [24] [25] [26], $G_{0}=$ the Afrikaner breed mean for the trait of interest and $G_{A}^{I}$ and $G_{A}^{M}$ were assumed to be zero. Other breed-specific effects were expressed as deviations from $G_{0}$. In calculating $P R, S R$ and $W R$ for $A H S$ dams, only the breed specific maternal genetic effects were available and the direct effects due to the genotype of the calf were assumed to be nil.

Finally, selection index weights for improvement of a ratio [31] were used to predict improvement in efficiency of the alternative systems $\left(T F C_{i} / T P_{i}\right)$ relative to the straightbred Afrikaner system. Specifically, the ratio of $T F C / T P$ in the straightbred Afrikaner system was the economic weight for $T P_{i}$ and the economic weight for $T F C_{i}$ was -1.0 . Thus,

$$
\text { Merit }_{i}=\left(T F C_{1} / T P_{1}\right) \times T P_{i}-T F C_{i} .
$$

\section{Results}

Simulation results for the fitness traits are presented in Table 1. Greater $P R$ were achieved by composite dams due to favorable breed additive effects and heterosis. Thus, a lower proportion of females were required to produce replacements with systems 4 and 5. Differences in calf $S R$ between two dam breeds were small and thus most of the advantage in $W R$ of composite dams was attributable to their greater $P R$. The decrease in $P R$ resulting from use of sexed semen resulted in similarly reduced $W R$ and greater $R R$ for systems 3 and 5.

Simulated results for productivity and the component traits for the breed groups simulated in this study are presented in Table 2 . The greatest $W W$ resulted from mating the Charolais terminal sire to composite dams with the resulting progeny being 25\% heavier than straightbred Afrikaner calves. Straightbred composite calves also approached this level of performance. Although Charolais sired calves from Afrikaner dams also had increased $W W(18.4 \%)$ relative to straightbred Afrikaner, the increase was not as great as for progeny of composite dams (25.2\%). Similarly, Charolais sired calves from Composite dams had the greatest $A D G$ and $D F I$. Further, due to the decreased number of days on 
feed required to attain 440 kilograms, Charolais $\times$ Composite calves consumed the least amount of feed during the time they were in the feedlot; approximately $29 \%$ less than straightbred Afrikaner. Both Charolais sired calves from Afrikaner dams and straightbred composite calves were intermediate between these breed groups for $A D G, D F I$, and TFI. There were no differences in DPs of the Afrikaner and composite straightbreds. However, use of the Charolais terminal sire resulted in a greater ratio of hot carcass weight to live weight. All crosses, which were approximately similar, improved meat yield from the carcass relative to straightbred Afrikaner. Thus, simulated $P$ was greatest when composite females were joined with Charolais sires.

Dividing the cow herd into two sections, producing replacement females $(R F)$ and the second producing market progeny $(M P)$ illustrates commitments of resources to components of the production system (Table 3 ). In each replacement section, females are allocated for production of replacements and contemporary males that are produced as a by-product are harvested and thus contribute to $\mathrm{P}$ and require feed. The number of by-product male calves is decreased when using sexed semen. Use of a Charolais terminal sire on a portion of the Afrikaner cows (System 2) increased P by 7\% over System 1 due to effects of breed complementarity and individual heterosis. Using sexed semen further improved $\mathrm{P}$ in production of market progeny in System 3, relative to System 2. However, this advantage was not sufficient to offset the loss in output that resulted from the reduced PR. Thus, total P of System 3 was less than that either System 1 or 2. With Systems 4 and 5, $P(T F)$ of the $R F$ section was reduced (increased) relative to Systems 2 and 3, respectively, due to the lesser number of females that were required in this section. Corresponding changes in $\mathrm{P}$ and $T F I$ of the $M P$ sections also result.

Using merit as a unified assessment of the systems, all systems that employed crossbreeding had greater merit than the straightbred Afrikaner production system (it was selected as the base to which the other systems were relative). Further, use of the composite specialized dam line increased merit relative to the corresponding system with a straightbred Afrikaner cow herd. Although using sexed semen increased the merit of System 3 slightly greater (3\%) than System 2, it did not result in any additional advantage in System 5 relative to System 4 that employed natural service.

\section{Discussion}

This study contemplated alternative production systems that could potentially improve beef production when making use of Afrikaner germplasm. It is based, in large part, on data collected in central South Africa near Jan Kempdorp at $27^{\circ} 51^{\prime}$ south and $24^{\circ} 50^{\prime}$ east, and an altitude of $1175 \mathrm{~m}$. Climatic conditions are classified as semi-arid with hot summers (average maximum temperature in December of $32^{\circ} \mathrm{C}$ ) and cold winters (average minimum temperature in July of $-0.5^{\circ} \mathrm{C}$ ). Average precipitation is approximately $450 \mathrm{~mm}$ per annum, of which 
Table 1. Simulated values for fitness traits applicable to straightbred Afrikaner and composite dam lines with natural service and use of sexed semen via artificial insemination.

\begin{tabular}{cccccc}
\hline Breeding System & & \multicolumn{4}{c}{ Fitness Traits (rates) } \\
\hline Method & Dam line & Pregnancy & Replacement & Calf survival & Weaning \\
\hline Natural & Afrikaner & 0.809 & 0.191 & 0.953 & 0.771 \\
Service & Composite & 0.873 & 0.127 & 0.970 & 0.849 \\
Sexed & Afrikaner & 0.728 & 0.272 & 0.953 & 0.694 \\
Semen & Composite & 0.786 & 0.214 & 0.970 & 0.762
\end{tabular}

Table 2. Simulated growth, feedlot and carcass values for progenies of Afrikaner and composite cattle as straightbreds and as crosses with a charolais terminal sire.

\begin{tabular}{ccccc}
\hline & \multicolumn{4}{c}{ Breed Group } \\
\cline { 2 - 5 } Trait & Afrikaner & $\begin{array}{c}\text { Charolais } \times \\
\text { Afrikaner }\end{array}$ & Composite & $\begin{array}{c}\text { Charolais } \times \\
\text { Composite }\end{array}$ \\
\hline Weaning wt., kg & 184.0 & 217.9 & 228.5 & 230.3 \\
Average daily gain, kg/d & 0.809 & 1.080 & 1.023 & 1.124 \\
Days to harvest & 316 & 206 & 207 & 187 \\
Daily feed intake, kg/d & 6.25 & 7.28 & 7.22 & 7.50 \\
Total feed intake, kg & 1977 & 1497 & 1494 & 1400 \\
Dressing, \% & 62.3 & 65.8 & 62.3 & 64.5 \\
Meat yield, \% & 81.6 & 82.7 & 82.9 & 82.9 \\
Productivity, kg (male calf) & 172.5 & 184.4 & 192.7 & 200.0 \\
\hline
\end{tabular}

Table 3. Commitments of resources and productivity per cow attributable to sections of the herd allocated to producing replacement females $(R F)$ and market progeny $(M P)$ for each of the simulated systems that were evaluated.

\begin{tabular}{|c|c|c|c|c|c|c|c|c|c|c|}
\hline \multirow[b]{3}{*}{$\begin{array}{l}\text { Cow herd } \\
\text { sections }\end{array}$} & \multicolumn{10}{|c|}{ Production System a } \\
\hline & \multicolumn{2}{|c|}{1} & \multicolumn{2}{|c|}{2} & \multicolumn{2}{|c|}{3} & \multicolumn{2}{|c|}{4} & \multicolumn{2}{|c|}{5} \\
\hline & $\mathrm{RF}$ & MP & RF & MP & $\mathrm{RF}$ & MP & $\mathrm{RF}$ & MP & $\mathrm{RF}$ & MP \\
\hline $\begin{array}{c}\text { Cows } \\
\text { allocated, \% }\end{array}$ & 38.2 & 61.8 & 38.2 & 61.8 & 30.2 & 69.8 & 25.4 & 74.6 & 23.8 & 76.2 \\
\hline $\begin{array}{l}\text { Calf sex ratio } \\
\text { (m:f) }\end{array}$ & $1: 1$ & $1: 1$ & $1: 1$ & $1: 1$ & $1: 9$ & $1: 1$ & $1: 1$ & $1: 1$ & $1: 9$ & $1: 1$ \\
\hline Productivity, kg & 32.9 & 95.9 & 32.9 & 102.5 & 4.7 & 115.8 & 24.5 & 134.1 & 4.2 & 137.0 \\
\hline $\begin{array}{l}\text { Total feed } \\
\text { intake, kg }\end{array}$ & 377.6 & 1221.7 & 377.6 & 925.4 & 59.3 & 1045.3 & 189.7 & 1044.3 & 35.9 & 1066.7 \\
\hline Relative merit & & & 37 & & & 91 & & 34 & & 49 \\
\hline
\end{tabular}


$88 \%$ is experienced between October and April. One concern about the data used herein regards its potentially being dated. However, similar crossbreeding studies that evaluate breeds in challenging environments such as this one have not been conducted more recently.

Here, the principal finding establishes the substantial benefit of a composite specialized dam line relative to either a straightbred production system or a production system that employs a terminal sire on straightbred dams. This is consistent with the substantial volume of literature on the benefits of crossbreeding [17] [32] [33]. However, this finding must be tempered by the recognition that use of non-adapted germplasm in stressful environments may not always be warranted [6] [34]. The superior adaptation of Afrikaner cattle relative to British breeds to hot, semi-arid, subtropical bushveld regions has long been recognized [35]. Further, the composite envisioned herein has similar breed composition to the Belmont Red that was developed by large pastoral companies in northern Australia to meet market specifications and maintain tropical adaptation [36] [37]. Growth performance, carcass merit and adaptive potential of the Belmont Red have been shown to be similar to that of Bonsmara, but with Belmont Red having a shorter calving interval [38]. As pointed out by [34], the environment for market progeny may be less severe than for females destined to become replacements and this may indicate a role for crossbreeding even in production environments where adaptation is of utmost importance for the cow herd. It has been recommended that adapted maternal lines should be crossed with large exotic terminal sire breeds to exploit breed complementarity for efficient gain, carcass quality and meat yield [5] [39]. The work of [40] supports this recommended paradigm.

At the outset, it seemed logical that if sexed semen would allow more females to be joined with a terminal sire that technology would support greater production efficiency. However, sex sorting sperm by flowcytometry is slow and along with post-processing damage limits the number of live sperm per dose produced. This results in fewer sperm then being used per insemination and a consequent reduction of fertility [41]. Recent literature supports the implicit assumption of similar pregnancy rates being achieved by natural service and artificial insemination [28] and the explicit assumption of a $10 \%$ decrease in PR when using sexed semen [20]. For System 3, which employs straightbred Afrikaner females, overall merit is slightly greater $(+3 \%)$ than for System 2 with a $10 \%$ reduction in pregnancy rate and $90 \%$ efficiency in sorting. If the sorting were perfect and sex-sorted semen was equivalent to unsorted semen in pregnancy rate, then the advantage of System 3 over System 2 would increase to 20\%. However, diverting additional females to the terminal sire by increasing the pregnancy rate and efficacy of sorting in use of sex-sorted semen only allows System 5 to marginally approach the merit of System 4 . Thus, the results suggest that when using highly fertile and productive composite females, there would be little if any additional advantage from breed complementarity. 


\section{Conclusion}

This simulation study demonstrates the utility of systems analysis techniques for summarizing a diverse body of data than it would be feasible to address experimentally. The results suggest that crossbreeding could be applied as a commercially appropriate technology to potentially improve production efficiency relative to a straightbred production system using adapted germplasm. However, not all state-of-the-art technologies will necessarily improve production efficiency, as is shown herein using the example of sexed semen. The compromised pregnancy rate and less than perfect sorting technology as well as limited opportunities for cost-effective implementation of artificial insemination prevent smallholders in stressful environments from fully capitalizing on benefits from crossbreeding.

\section{References}

[1] Delgado, C., Rosegrant, M., Steinfeld, H., Ehui, S. and Courbois, C. (1999) Livestock to 2020: The Next Food Revolution. International Food Policy Research Institute, Washington DC.

[2] McLeod, A. (2011) World Livestock 2011-Livestock in Food Security. Food and Agriculture Organization of the United Nations (FAO), Rome.

[3] Ehui, S.H., Li-Pun, H.H., Mares, V. and Shapiro, B. (1998) The Role of Livestock in Food Security and Environmental Protection. Outlook on Agriculture, 27, 81-87.

[4] Hazell, P., Poulton, C., Wiggins, S. and Dorward, A. (2007) The Future of Small Farms for Poverty Reduction and Growth. International Food Policy Research Institute (IFPRI), Washington DC. http://www.ifpri.org/2020/dp/vp42.asp

[5] Scholtz, M.M. and Theunissen, A. (2010) The Use of Indigenous Cattle in Terminal Crossbreeding to Improve Beef Cattle Production in Sub-Saharan Africa. Animal Genetics Research, 46, 33-39. https://doi.org/10.1017/S2078633610000676

[6] Burrow, H.M. (2012) Importance of Adaptation and Genotype X Environment Interactions in Tropical Beef Breeding Systems. Animal, 6, 729-740. https://doi.org/10.1017/S175173111200002X

[7] Pienaar, L. (2014) Genetic Diversity in the Afrikaner Cattle Breed. MSc. Thesis, University of the Free State, Bloemfontain.

[8] MacNeil, M.D., Cundiff, L.V., Dinkel, C.A. and Koch, R.M. (1984) Genetic Correlations among Sex-Limited Traits in Beef Cattle. Journal of Animal Science, 58, 1171-1180. https://doi.org/10.2527/jas1984.5851171x

[9] MacNeil, M.D., Bailey, D.R., Urick, J.J., Gilbert, R.P. and Reynolds, W.L. (1991) Heritabilities and Genetic Correlations for Postweaning Growth and Feed Intake of Beef Bulls and Steers. Journal of Animal Science, 69, 3183-3189. https://doi.org/10.2527/1991.6983183x

[10] MacNeil, M.D., Lopez-Villalobos, N. and Northcutt S.L. (2011) A Prototype National Cattle Evaluation for Feed Intake and Efficiency of Angus Cattle. Journal of Animal Science, 89, 3917-3923. https://doi.org/10.2527/jas.2011-4124

[11] Greiner, S.P. (2002) Crossbreeding in Beef Cattle. Virginia Polytechnic Institute and State University, Blacksburg.

[12] Scholtz, M.M., Steyn, Y., Van Marle-Koester, E. and Theron, H.E. (2012) Improved Production Efficiency in Cattle to Reduce their Carbon Footprint for Beef Production. South African Journal of Animal Science, 42, 450-453. 
[13] Cartwright, T.C. (1970) Selection Criteria for Beef Cattle for the Future. Journal of Animal Science, 30, 706-711. https://doi.org/10.2527/jas1970.305706x

[14] Gregory, K.E. and Cundiff, L.V. (1980) Crossbreeding in Beef Cattle: Evaluation of Systems. Journal of Animal Science, 51, 1224-1242. https://doi.org/10.2527/jas1980.5151224x

[15] MacNeil, M.D. and Matjuda, E. (2007) Breeding Objectives for Angus and Charolais Specialized Sire Lines for Use in the Emerging Sector of South African Beef Production. South African Journal of Animal Science, 37, 1-10.

[16] Gutierrez-Gil, B., Wiener, P. and Williams, J.L. (2007) Genetic Effects on Coat Colour in Cattle: Dilution of Eumelanin and Phaeomelanin Pigments in an F2-Backcross Charolais x Holstein Population. BMC Genetics, 8, 56. https://doi.org/10.1186/1471-2156-8-56

[17] Dadi, H., Jordaan, G.F., Schoeman, S.J. and Van der Westhuizen, J. (2002) The Effect of Charolais and Hereford Sires and Straightbred and Crossbred Dams on Pre-weaning Growth of Calves. South African Journal of Animal Science, 32, 38-43. https://doi.org/10.4314/sajas.v32i1.3789

[18] Theunissen, A. (2012) Charaterization of Breed Additive and Heterosis Effects in Beef Cattle Using Experimental Results. Master's Thesis, University of Free State, Bloemfontein.

[19] MacNeil, M.D. (2005) Beef Cattle Management: Crossbreeding. In: Ullrey, D.E., et al., Eds., Encyclopedia of Animal Science, CRC Press, Boca, Raton.

[20] Hall, J.B. and Glaze Jr, J.B. (2013) How Can Sexed Semen Be Used in Commercial Beef Herds? Range Beef Cow Symposium, Rapid City, 3-5 December 2013, 316. http://digitalcommons.unl.edu/rangebeefcowsymp/316

[21] Hohenboken, W.D. (1999) Applications of Sexed Semen in Cattle Production. Theriogenology, 52, 1421-1433. https://doi.org/10.1016/s0093-691x(99)00227-7

[22] Maqhashu, A., Mphaphathi, M.L., Seshoka, M.M., Ramukhithi, F.V., Seolwana, F.L., Masenya, M.B., Netshirovha, R.T., Mapeka, M.H., Nengovhela, N.H., Kanuya, N.L., Muchenje, V. and Nedambale, T.L. (2016) Comparison of Oestrous Synchronization Response and Pregnancy Rate of Village Cows Following Timed Artificial Insemination in KwaZulu-Natal and Limpopo Provinces. Open Journal of Animal Sciences, 6, 9-15. https://doi.org/10.4236/ojas.2016.61002

[23] Long, C.R., Cartwright, T.C. and Fitzhugh, H.A. (1975) Systems Analysis of Sources of Genetic and Environmental Variation in Efficiency of Beef Production: Cow Size and Herd Management. Journal of Animal Science, 40, 409-420. https://doi.org/10.2527/jas1975.403409x

[24] Theunissen, A., Scholtz, M.M., Neser, F.W.C. and MacNeil, M.D. (2013) Crossbreeding to Increase Beef Production: Additive and non-Additive Effects on Weight Traits. South African Journal of Animal Science, 43, 143-152.

[25] Theunissen, A., Scholtz, M.M., MacNeil, M.D. and Neser, F.W.C. (2014) Breed Additive and Heterosis Effects on Feedlot and Carcass Traits in Beef Cattle. 10th World Congress on Genetics Applied to Livestock Production, Vancouver, 17-22 August 2014, 714.

[26] Theunissen, A., Scholtz, M.M., Neser, F.W.C. and MacNeil, M.D. (2014) Crossbreeding to Increase Beef Production: Additive and non-Additive Effects on Fitness Traits. South African Journal of Animal Science, 44, 335-349. https://doi.org/10.4314/sajas.v44i4.3

[27] Seidel, G.E. (2003) Economics of Selecting for Sex: The Most Important Genetic Trait. Theriogenology, 59, 585-598. https://doi.org/10.1016/S0093-691X(02)01242-6 
[28] Lardner, B. and Damiran, D. (2015) Comparison of Fixed-time Artificial Insemination vs. Natural Service in Beef Cows: Reproductive Efficiency and System Cost. http://www.wbdc.sk.ca/pdfs/fact sheets/2015/2015-02 WBDC_Fixed-timeAI vs N aturalBreeding.pdf

[29] Anderson, P. (2012) Matching Cattle Type and Feedlot Performance. University Minnesota Extension.

http://www.extension.umn.edu/agriculture/beef/components/pdfs/matching cattle type and feedlot performance.pdf

[30] Dickerson G.E. (1973) Inbreeding and Heterosis in Animals. Proceedings of an Animal Breeding Symposium in Honor of Jay Lush. American Society of Animal Science and American Dairy Science Association, Illinois, 29 July 1972, 54-77.

[31] Lin, C.Y. (1980) Relative Efficiency of Selection Methods for Improvement of Feed Efficiency. Journal of Dairy Science, 63, 491-494. https://doi.org/10.3168/jds.S0022-0302(80)82960-2

[32] MacNeil, M.D., Cundiff, L.V., Gregory, K.E. and Koch, R.M. (1988) Crossbreeding Systems for Beef Production. Applied Agricultural Research, 3, 44-54.

[33] Skrypzeck, H., Schoeman, S.J., Jordaan, G.F. and Neser, F.W.C. (2000) Estimates of Crossbreeding Parameters in a Multibreed Beef Cattle Crossbreeding Project. South African Journal of Animal Science, 30, 193-203. https://doi.org/10.4314/sajas.v30i3.3852

[34] Barwick, S.A., Johnston, D.J., Burrow, H.M., Holroyd, R.G., Fordyce, G., Wolcott, M.L., Sim, W.D. and Sullivan, M.T. (2009) Genetics of Heifer Performance in Wet and Dry Seasons and their Relationships with Steer Performance in Two Tropical Beef Genotypes. Animal Production Science, 49, 367-382.

https://doi.org/10.1071/EA08273

[35] Bonsma, J.C. (1949) Breeding Cattle for Increased Adaptability to Tropical and Subtropical Environments. Journal of Agricultural Science, 39, 204-221. https://doi.org/10.1017/S0021859600005037

[36] Rudder, T.H., Bean, K.G., Lapworth, J.W. and Seifert, G.W. (1976) Commercial Evaluation of a Tropical Breed Developed Experimentally. Proceeding of the Australian Society of Animal Production, 11, 89-92.

[37] Seifert, G.W. and Rudder, T.H. (1984) Experience with Africander and Africander Derived Genotypes in Australian Beef Herds. Proceedings of the 2 nd World Congress on Sheep and Beef Cattle Breeding, 16-19 April 1984, Pretoria, 671-677.

[38] Corbet, N.J., Shepherd, R.K., Burrow, H.M., van der Westhuizen, J., Strydom, P.E. and Bosman, D.J. (2006) Evaluation of Bonsmara and Belmont Red Breeds in South Africa. 1. Productive Performance. Australian Journal of Experimental Agriculture, 46, 199-212. https://doi.org/10.1071/EA05223

[39] Scholtz, M.M., Roux, C.Z. and Lombard, P.E. (1990) Breeding Strategies for Beef Cattle in the Subtropics and Tropics: Terminal Crossbreeding. Proceedings of the 4th World Congress on Genetics Applied to Livestock Production, 23-27 July 1990, Edinburgh, XV, 361-364.

[40] Moyo, S. (1990) Evaluation of the Productivity of Indigenous Cattle and Some Exotic Beef Breeds and their Crosses in Zimbabwe. In: Ababa, A., Ed., ILCA Research Fellowship Report, ILCA, Ethiopia, 139.

[41] Garner, D.L. and Seidel, G.E. (2008) History of Commercializing Sexed Semen for Cattle. Theriogenology, 69, 886-895.

https://doi.org/10.1016/j.theriogenology.2008.01.006 
Submit or recommend next manuscript to SCIRP and we will provide best service for you:

Accepting pre-submission inquiries through Email, Facebook, LinkedIn, Twitter, etc. A wide selection of journals (inclusive of 9 subjects, more than 200 journals)

Providing 24-hour high-quality service

User-friendly online submission system

Fair and swift peer-review system

Efficient typesetting and proofreading procedure

Display of the result of downloads and visits, as well as the number of cited articles Maximum dissemination of your research work

Submit your manuscript at: http://papersubmission.scirp.org/

Orcontact as@scirp.org 